Ristekdik (Jurnal Bimbingan dan Konseling)

Vol.6, No.2, 2021, hlm.202-212

DOI: http://dx.doi.org/10.31604/ristekdik.2021.v6i2.202-212

ISSN 2541-206X (online)

ISSN 2527-4244 (cetak)

\title{
EFEKTIVITAS LAYANAN KONSELING KELOMPOK KONTRAK PERILAKU UNTUK MENGURANGI PERILAKU BERMAIN GAME ONLINE DI RUMAH (Studi Eksperimen Kuasi Siswa Kelas VIII di SMP Negeri 15 Palu)
}

\author{
${ }^{1}$ Mardi Lestari, ${ }^{2}$ Nurul Fitriah Aras, ${ }^{3}$ Nur Fauziah, ${ }^{4}$ Andi Wahyu Irawan, ${ }^{5}$ Muhammad \\ Junaedi Mahyuddin \\ ${ }^{1}$ Program Studi Bimbingan dan Konseling-Universitas Tadulako \\ ${ }^{2}$ Program Studi Pendidikan Guru Sekolah Dasar-Universitas Tadulako \\ ${ }^{3}$ Mahasiswa Program Studi Bimbingan dan Konseling-Universitas Tadulako \\ ${ }^{4}$ Program Studi Bimbingan dan Konseling-Universitas Mulawarman \\ ${ }^{5}$ Program Studi Bimbingan dan Konseling-STKIP Muhammadiyah Enrekang \\ lestarimardi@untad.ac.id
}

\begin{abstract}
The main problem of this research is the habit of playing online games by students at home. The main purpose of this study is to explain that the behavior group counseling service is to reduce the behavior of playing online games at home. This research uses quantitative research with the One Group Pretest-Posttest Design model. The research sample used purposive sampling method as many as 6 students of SMP Negeri 15 Palu. The questionnaire result data analysis used descriptive and inferential analysis based on the Wilcoxon sign rank test formula. The results of the descriptive analysis show that the behavior of playing online games at home before participating in the behavioral group counseling services, among others: 6 students, namely MAB, MRA, YL, J, MR and MRT have a high intensity of playing online games at home. After being provided with behavioral contract group counseling services, 3 students with the initials MRA, YL and MRT have high online game play behavior, 3 students namely $M A B, M R$, and $J$ have low online game play behavior. The results of inferential analysis show that the behavior of playing online games at home after participating in the behavior group counseling service is lower than before attending the behavior group counseling service. The results showed that the behavior group counseling service was effective in reducing the behavior of playing online games at home.
\end{abstract}

Keywords: Group counseling service, behavioral contract, online game, behavioral

\begin{abstract}
Abstrak: Permasalahan utama penelitian ini adalah kebiasaan bermain game online oleh siswa di rumah. Tujuan utama penelitian ini adalah menjelaskan efektivitas layanan konseling kelompok kontrak perilaku untuk mengurangi perilaku bermain game online di rumah. Penelitian ini menggunakan jenis penelitian kuantitatif dengan model One Grup Pretest-Posttes Design. Sampel penelitian ini menggunakan metode purposive sampling sebanyak 6 orang siswa SMP Negeri 15 Palu. Data hasil angket analisis dengan menggunakan analisis deskriptif dan inferensial berdasarkan rumus Wilcoxon sign rank test. Hasil analisis deskriptif menunjukkan bahwa perilaku bermain game online di rumah sebelum mengikuti layanan konseling kelompok kontrak perilaku, antara lain: 6 siswa yaitu MAB, MRA, YL, J, MR dan MRT memiliki intensitas tinggi bermain game online di rumah. Setelah diberikan layanan konseling kelompok kontrak perilaku, 3 siswa berinisial MRA, YL dan MRT memiliki perilaku bermain game online tinggi, 3 siswa yaitu MAB, MR, dan J memiliki perilaku bermain game online rendah. Hasil analisis inferensial menunjukkan bahwa perilaku bermain game online di rumah setelah mengikuti layanan konseling kelompok kontrak perilaku lebih rendah dibanding sebelum mengikuti layanan konseling kelompok kontrak perilaku. Hasil penelitian menunjukkan bahwa layanan konseling kelompok kontrak perilaku efektif untuk mengurangi perilaku bermain game online di rumah.
\end{abstract}

Kata kunci: Layanan Konseling Kelompok, Kontrak Perilaku, Perilaku Bermain Game Online, Perilaku. 


\section{PENDAHULUAN}

Pendidikan merupakan suatu hal yang penting yang harus dimiliki oleh setiap bangsa karena dengan pendidikan yang berkualitas suatu bangsa menjadi maju dan sejahtera. Pendidikan diperlukan untuk meningkatkan harkat, martabat, dan kesejahteraan manusia. Menurut Undang- Undang No.20 tahun 2003 Pasal 1 menyebutkan bahwa pendidikan adalah usaha sadar dan terencana untuk mewujudkan suasana belajar dan proses pembelajaran agar peserta didik secara aktif mengembangkan potensi dirinya untuk memiliki kekuatan spiritual keagamaan, pengendalian diri, kepribadian, kecerdasan, akhlak mulia, serta keterampilan yang diperlukan dirinya, masyarakat, bangsa dan negara.

Sekolah adalah lembaga formal tempat siswa menimba ilmu dalam mengembangkan minat, bakat, dan kemampuan untuk mencapai keberhasilan di masa depan. Di sekolah kegiatan belajar mengajar berlangsung, ilmu pengetahuan diajarkan dan dikembangkan kepada siswa. Belajar merupakan proses yang ditandai dengan adanya perubahan diri seseorang (Ningsih, 2018:1).

Menurut (Haris Budiman, 2017) mengatakan bahwa teknologi informasi dan komunikasi adalah payung besar terminologi yang mencakup seluruh peralatan teknis untuk memproses dan menyampaikan informasi. Kemajuan teknologi informasi dan komunikasi yang sangat pesat menuntut pengguna untuk jeli memilih berbagai informasi yang diterima. Penggunaan internet di Indonesia semakin meningkat seiring dengan faktor pendukung yang memudahkan manusia untuk mengakses internet baik menggunakan komputer, notebook, ataupun handphone. Salah satu yang dapat diakses melalui internet ialah game online. Jumlah pemain game online di Indonesia terus meningkat setiap tahunnya. Hasil survey menunjukkan bahwa jumlah pemain game online di Indonesia meningkat antara 5\%-10\% setiap tahunnya di mana pada tahun 2014 terdapat 25 juta orang Indonesia telah bermain game online (Tribunnews.com).

Pengguna game online tidak hanya dari kalangan dewasa, banyak anak-anak dan remaja yang berpartisipasi dalam permainan game online. Remaja yang tumbuh dan berkembang pada era millenium saat ini akan bersinggungan dengan banyaknya kecanggihan teknologi yang memudahkan untuk memperoleh berbagai informasi yang dibutuhkan (Novrialdy, Nirwana \& Ahmad, 2019). Anak-anak atau remaja begitu mudah tertarik dalam permainan online karena dimanjakan dengan pilihan dari jenis permainan yang beragam atau variatif. Remaja yang bermain game online mempunyai motif yang berbeda, ada yang bermain game sekedar hobi, hiburan, pelampiasan emosi, mencari teman, serta telah menjadi bagian dari dirinya sendiri (Lombogia, 2018).

Gamer atau pemain game terdorong untuk bermain game karena menginginkan pengakuan akan prestasi dalam bermain game yang dilakukan dengan mengatasi rintangan yang sulit sehingga meraih tingkatan yang lebih tinggi. Game online membuat para pemain 
merasa senang menggunakannya karena memberikan sensasi dan menantang sehingga pemain game online lupa waktu karena dimainkan secara online dengan orang-orang yang berada jauh (Nurul Ismi dan Akmal, 2020).

Memainkan game online dapat mempengaruhi perilaku belajar siswa. Tingginya tingkat bermain game online dapat terjadi karena kurangnya kontrol diri dalam diri individu sehingga kurang mampu mengantisipasi dampak negatif yang timbul dari bermain game online secara berlebihan (Masya dan Candra, 2016). Perilaku bermain game online jika dilakukan secara berulangulang akan menimbulkan kecanduan (Sri Lutfiwati,2018). Game online yang semula berfungsi sebagai pembunuh kejenuhan, melatih keahlian fisikdan mental,dapat berubah menjadi ancaman serius bagi kesehatan dan mental anak apabila anak tersebut memainkan game dengan durasi yang cukup lama dan tingkat seringnya bermain game online mulai berlebihan dan tidak dapat dikontrol lagi.

Berdasarkan pengamatan dan wawancara dengan guru Bimbingan dan Konseling yang peneliti lakukan di SMP Negeri 15 Palu, terdapat beberapa siswa yang kerap mengerjakan pekerjaan rumah (PR) di sekolah dengan alasan lupa karena keasikan bermain game online. Perilaku game online rata-rata dilakukan siswa karena merasa senang, terhibur dan untuk mengusir kejenuhan.

Peraturan Menteri Pendidikan dan Kebudayaan Republik Indonesia Nomor III Tahun 2014 Pasal 1 Menyebutkan bahwa
Bimbingan dan Konseling adalah upaya sistematis, objektif, logis, atau berkelanjutan serta terprogram yang dilakukan konselor atau guru Bimbingan dan Konseling untuk memfasilitasi perkembangan peserta didik untuk mencapai kemandirian dalam hidupnya.

Salah satu layanan yang dapat diberikan oleh guru Bimbingan dan Konseling adalah layanan konseling kelompok. Menurut (Josef Dudi, 2017) konseling kelompok merupakan suatu proses yang melibatkan pemimpin kelompok yaitu guru Bimbingan dan Konseling dalam hubungan dengan sejumlah anggota kelompok yaitu siswa pada waktu yang sama, jumlahnya dapat bervariasi dalam setiap kelompok. Konseling kelompok adalah suatu layanan yang diberikan kepada sekelompok individu guna mengatasi masalah yang relatif sama, sehingga individu tidak mengalami hambatan untuk mengembangkan segenap potensi yang dimiliki (Hardi Prasetiawan, 2017).

Menurut (Chalimi. M. K, 2017) kontrak perilaku adalah salah satu teknik pembelajaran pendekatan konseling terapi behavioral yang dapat digunakan untuk membantu menyelesaikan permasalahan perilaku maladaptif pada diri konseli yang berkeinginan mengubah perilaku tersebut menjadi lebih baik. Teknik kontrak perilaku dapat digunakan untuk mengajarkan perilaku baru, mengurangi perilaku yang tidak diinginkan, atau meningkatkan perilaku yang diharapkan (Erford, 2017). Landasan dari penggunaan teknik kontrak perilaku karena tingkah laku dapat dipelajari dan dapat diubah dengan memberikan 
penguatan segera setelah tingkah laku yang diharapkan muncul (Dewi dan Titin, 2016) Suatu layanan yang diberikan kepada sekelompok individu guna mengatasi masalah yang relatif sama, sehingga individu tidak mengalami hambatan untuk mengembangkan segenap potensi yang dimiliki (Hardi Prasetiawan, 2016). Dengan menggunakan teknik kontrak perilaku konselor berupaya membantu konseli dalam mengubah perilaku maladaptif menjadi perilaku adaptif dengan membuat sebuah perjanjian tertulis yang disepakati oleh konselor dan konseli.

\section{METODE}

Penelitian ini menggunakan pendekatan kuantitatif. Pendekatan kuantitatif menurut Arikunto (2006:12) adalah penelitian yang banyak menggunakan angka-angka, mulai dari pengumpulan data, penafsiran terhadap data serta penampilan dari hasilnya. Jenis Penelitian yang digunakan adalah eksperimen semu (quasi experiment research). Menurut Sugiono (2017, 72) eksperimen kuasi digunakan untuk mencaripengaruh perlakuan terhadap yang lain dalamkondisi yang terkendali.

Penelitian ini menggunakan rancangan One Group Pretest-Posttes Design. Pelaksanaan penelitian dilakukan dengan memberikan angket sebanyak dua kali tahap pertama diberikan sebelum dilakukan layanan konseling kelompok kontrak perilaku angket kedua diberikan sesudah dilakukan layanan konseling kelompok kontrak perilaku.

Rancangan penelitian ini diuraikan sebagai berikut:

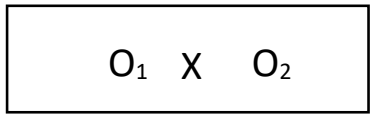

(Sugiyono.2010,111)

\section{Gambar 3.1. Rancangan Penelitian}

\section{Keterangan:}

O1 : Pemberian angket perilaku bermain game online di rumah sebelum diberikan layanan konseling kelompok kontrak perilaku.

X : Pemberian layanan konseling kelompok kontrak perilaku.

O2 : Pemberian angket perilaku bermain game online di rumah sesudah diberikan layanan konseling kelompok kontrak perilaku.

Penelitian ini dilaksanakan di SMP Negeri15 Palu yang berlokasi di jalan Imam Hi hayyun, Kota Palu, Sulawesi Tengah. Waktu penelitian dilakukan selama 1 bulan mulai pada bulan November 2020 sampai bulan Desember 2020. Subjek penelitian adalah 6 siswa kelas VIII SMP Negeri 15 yang memiliki perilaku bermain game online di rumah lebih dari 12 jam perhari.

Instrumen yang digunakan dalam penelitian ini adalah angket. Angket merupakan suatu alat ukur untuk mengumpulkan data tentang diri individu berdasarkan data yang dibutuhkan. Angket yang digunakan untuk 
mengumpulkan data perilaku bermain game online siswa.

Angket ini berisikan 15 item pernyataan mengenai perilaku bermain game online dengan menggunakan 3 indikator yaitu: tempat bermain game online, waktu dalam bermain game online, dan jenis game online yang dimainkan. Setiap penyataan terdiri dari4 pilihan jawaban yaitu selalu (SL), sering (SR), kadang-kadang (KD), dan tidak pernah (TP).Prosedur skala sebagai berikut:
Tabel 3.1 Prosedur skala

\begin{tabular}{cc}
\hline Interval & Kategorisasi \\
\hline $80-100$ & Sangat Tinggi \\
\hline $60-79$ & Tinggi \\
\hline $40-59$ & Rendah \\
\hline$\leq 40$ & Sangat Rendah \\
\hline
\end{tabular}

(Thalib M. M, 2007)

Pengujian hipotesis dilakukan untuk mengetahui apakah hipotesis nol (Ho) diterima atau ditolak maka hasil perhitungan dikonsultasikan pada nilai ttabel dengan taraf kepercayaan $95 \% \quad(\alpha=0,5) . \quad$ Jika nilai thitung $\leq$ nilai ttabel maka hipotesis nihil $(\mathrm{Ho})$ ditolak. sebaliknya jika thitung $\geq$ nilai ttabel maka hipotesis nol (Ho) tidak ditolak.

Tahap Pelaksanaan Konseling kelompok Kontrak Perilaku pada penelitian ini dapat di lihat pada alur proses berikut ini:

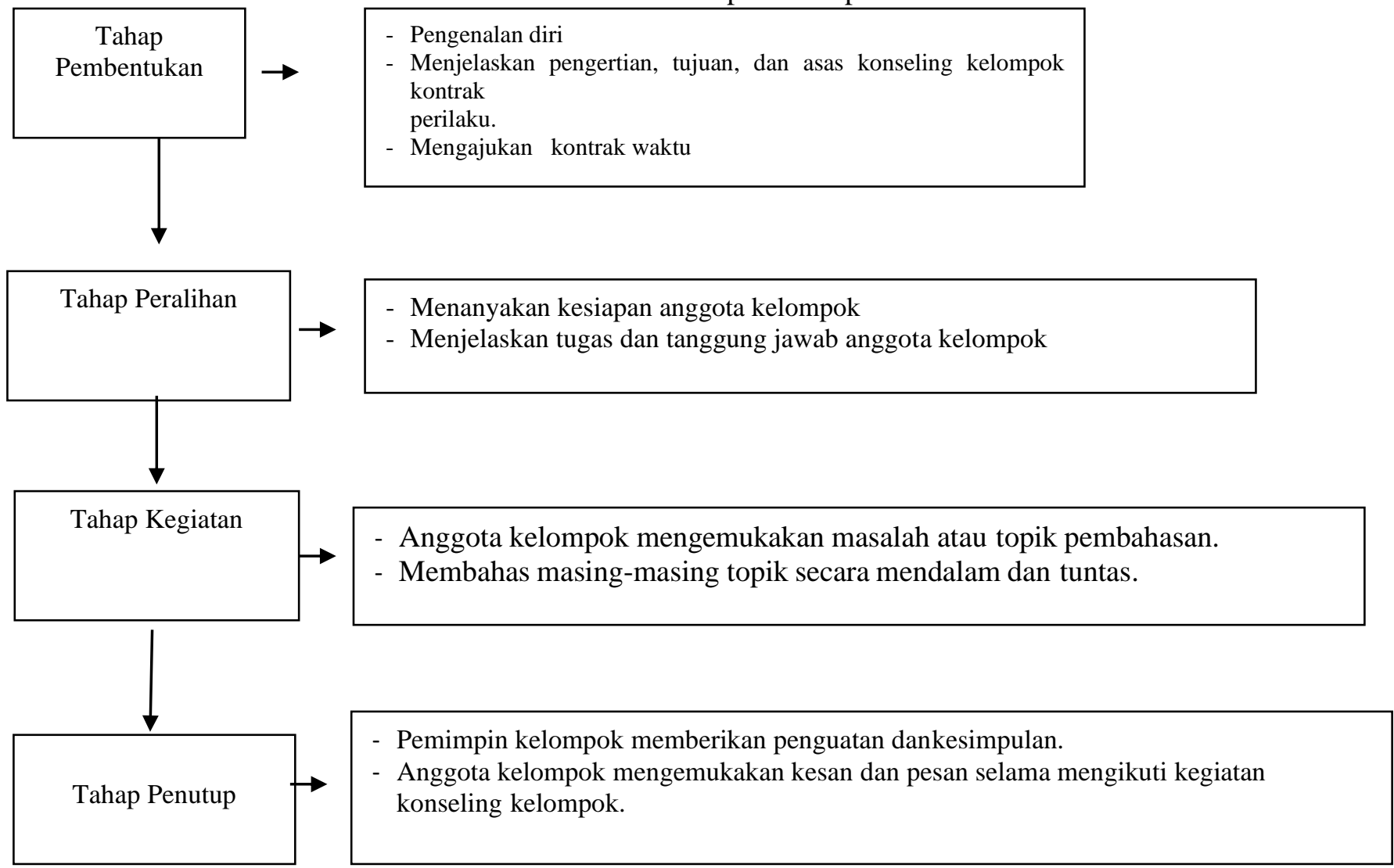


HASIL

\section{Hasil Pengujian Statistik Deskriptif}

Hasil analisis deskriptif perilaku bermain game online di rumah siswa kelas VIII SMP
Negeri 15 Palu sebelum mengikuti layanan konseling kelompok kontrak perilaku dapat diuraikan pada Tabel 4.1 sebagai berikut:

Tabel 4.1 Presentase Perilaku Bermain Game Online Sebelum Mengikuti Layanan Konseling Kelompok Kontrak Perilaku.

\begin{tabular}{llccl}
\hline No & Subjek & Skor & $\begin{array}{c}\text { Presentase } \\
(\boldsymbol{\%})\end{array}$ & $\begin{array}{c}\text { Klasifikasi Perilaku } \\
\text { Bermain Game }\end{array}$ \\
Online & & & Di Rumah \\
\hline 1 & MAB & 31 & 68,8 & Tinggi \\
\hline 2 & MRA & 33 & 73,3 & Tinggi \\
\hline 3 & YL & 29 & 64,4 & Tinggi \\
\hline 4 & J & 28 & 62,2 & Tinggi \\
\hline 5 & MR & 27 & 60 & Tinggi \\
\hline 6 & MRT & 30 & 66,6 & Tinggi \\
\hline
\end{tabular}

Hasil analisis deskriptif perilaku bermain konseling kelompok kontrak perilaku, dapat game online di rumah siswa kelas VIII SMP diketahui pada pedoman klasifikasi yang Negeri 15 Palu setelah mengikuti layanan ditunjukkan pada tabel berikut ini:

Tabel 4.2 Presentase Perilaku Bermain Game Online Sesudah Mengikuti Layanan Konseling Kelompok Kontrak Perilaku.

\begin{tabular}{|c|c|c|c|c|}
\hline No & Subjek & Skor & $\begin{array}{c}\text { Presentase } \\
\qquad(\%)\end{array}$ & $\begin{array}{c}\text { Klasifikasi Perilaku } \\
\text { Bermain Game }\end{array}$ \\
\hline \multicolumn{5}{|c|}{ Online } \\
\hline 1 & MAB & 24 & 53,3 & Rendah \\
\hline 2 & MRA & 27 & 60 & \\
\hline \multicolumn{5}{|c|}{ Tinggi } \\
\hline 3 & YL & 28 & 62,2 & Tinggi \\
\hline 4 & $\mathrm{~J}$ & 23 & 51,1 & Rendah \\
\hline 5 & MR & 18 & 40 & Rendah \\
\hline 6 & MRT & 28 & 62,2 & Tinggi \\
\hline
\end{tabular}


Perilaku bermain game online di rumah pada pengklasifikasian perilaku bermain game siswa kelas VIII SMP Negeri 15 Palu sebelum online di rumah siswa kelas VIII SMP Negeri dan sesudah mengikuti layanan konseling 15 Palu yang ditujukkan pada tabel berikut ini: kelompok kontrak perilaku dapat diketahui

Tabel 4.3 Klasifikasi Perilaku Bermain Game Online Sebelum dan Sesudah Mengikuti Layanan Konseling Kelompok Kontrak Perilaku.

\begin{tabular}{llccccc}
\hline No Subjek & \multicolumn{2}{c}{ Sebelum } & \multicolumn{2}{c}{$\begin{array}{c}\text { Sesudah } \\
\text { Mengikuti }\end{array}$} & Keterangan \\
& & \multicolumn{2}{c}{$\begin{array}{c}\text { Mengikuti } \\
\text { LKKKP }\end{array}$} & \multicolumn{2}{c}{ LKKKP } & \\
\cline { 2 - 6 } & & Presentase & Klasifikasi & Presentase & Klasifikasi & \\
\hline 1 & MAB & 68,8 & Tinggi & 53,3 & Rendah & Berkurang \\
\hline 2 & MRA & 73,3 & Tinggi & 60 & Tinggi & Tetap \\
\hline 3 & YL & 64,4 & Tinggi & 62,2 & Tinggi & Tetap \\
\hline 4 & J & 62,2 & Tinggi & 51,1 & Rendah & Berkurang \\
\hline 5 & MR & 60 & Tinggi & 40 & Rendah & Berkurang \\
\hline 6 & MRT & 66,6 & Tinggi & 62,2 & Tinggi & Tetap \\
\hline
\end{tabular}

\section{Hasil Pengujian Analisis Statistik Inferensial}

Pengujian hipotesis dilakukan melalui analisis tersebut menggunakan tabel persiapan analisis secara statistik dengan menggunakan T Wilcoxon sebagai berikut: rumus Wilcoxon sign rank test. Perhitungan

Tabel 4.4 Data Perilaku Bermain Game Online Siswa Di Rumah SMP Negeri 15 Palu Sebelum dan Sesudah Mengikuti Layanan Konseling Kelompok Kontrak Perilaku.

\begin{tabular}{lcccccc}
\hline Siswa & X & Y & D & Rd & Rd Positif & Rd Negatif \\
\hline MAB & 31 & 20 & 11 & 6 & +6 & 0 \\
\hline MRA & 33 & 29 & 4 & 2 & +2 & 0 \\
\hline YL & 29 & 24 & 5 & 3 & +3 & 0 \\
\hline J & 28 & 20 & 8 & 4 & +4 & 0 \\
\hline MR & 27 & 18 & 9 & 5 & +5 & 0 \\
\hline MRT & 30 & 28 & 2 & 1 & +1 & 0 \\
\hline \multicolumn{7}{l}{ Jumlah T Wilcoxon } \\
\hline
\end{tabular}


Berdasarkan tabel di atas diperoleh nilai $\mathrm{T}$ Wilcoxon $=0$, sedangkan untuk nilai $\mathrm{N}=6$ dengantaraf kepercayaan 95\% $(\alpha=0,05)$, diperoleh nilai $\mathrm{T}$ tabel $=2$. Berdasarkan nilai tersebut menunjukkan bahwa nilai Thitung < Ttabel atau $0<2$. Dapat disimpulkan bahwa hipotesis nol (H0) yang berbunyi perilaku bermain game online siswa di rumah kelas VIII SMP Negeri 15 Palu sesudah diberikan layanan

\section{PEMBAHASAN}

Terdapat 6 siswa yang memiliki perilaku bermain game online tinggi sebelum diberikan perlakuan. Berdasarkan hasil analisis deskriptif, setelah dilakukan perlakuan, ternyata jumlah siswa berperilaku bermain game yang tingg, berkurang menjadi 3 siswa yaitu MAB, MR dam J memiliki klasifikasi rendah. Sedangkan tiga siswa lain yang masih tinggi perilaku bermain gamenya adalah MRA, Y dan MRT memiliki klasifikasi tinggi.

Hasil analisis deskriptif dan analisis inferensial memberikan gambaran bahwa adanya pengurangan perilaku bermain game online di rumah sesudah mengikuti layanan konseling kelompok kontrak perilaku dibandingkan sebelum mengikuti layanan konseling kelompok kontrak perilaku diperkuat dengan perolehan nilai Thitung $=0$, sedangkan nilai untun $\mathrm{N}=6$ dengan taraf kepercayaan $95 \%(\alpha=0,05)$, diperoleh nilai t_tabel $=2$, berdasarkan nilai tersebut dapat ditunjukkan bahwa nilai t_hitung $\leq \mathrm{t} \_$tabel, atau $0 \leq 2$. Maka hipotesis nol (H0) yang berbunyi pemberian layanan konseling kelompok kontrak perilaku konseling kelompok kontrak perilaku berpengaruh dalam mengurangi perilaku bermain game online sebelum diberikan layanan konseling kelompok ternyata tidak ditolak. Dengan demikian dapat disimpulkan bahwa pemberian layanan konseling kelompok kontrak perilaku efektif dalam pengurangan perilaku bermain game online siswa di rumah SMP Negeri 15 palu. efektif untuk mengurangi perilaku bermain game online di rumah siswa kelas VIII SMP Negeri 15 Palu.

Siswa yang mengalami pengurangan perilaku bermain game online dikarenakan adanya kesediaan untuk mengikuti setiap sesi layanan dengan penuh perhatian dan antusias. Sesuai dengan penelitian Astriana( dalam Atika Tera. P, 2016) yang menjelaskan bahwa dengan melaksanakan layanan konseling kelompok teknik behavior contract dengan baik maka dapat secara efektif menurunkan permasalahan penggunaan smartphone siswa. Selain itu, adanya kesadaran diri dan kemauan yang besar untuk mengubah perilaku yang kurang tepat tersebut.

Berdasarkan hasil penelitian Sukarti (2018:55) membuktikan konseling kelompok dengan teknik kontrak perilaku efektif untuk mengurangi perilaku bullying verbal pada siswa. Hasil penelitian Yulia Miftahul jannah (2019) yang berjudul konseling Islam dengan teknik kontrak perilaku untuk mengatasi perilaku kecanduan game online menyatakan bahwa terjadi perubahan perilaku maladaptif menjadi 
perilaku adaptif dalam diri konseli. Sejalan dengan penelitian Prasetiawan (2016) mengatakan bahwa konseling kelompok dapat mereduksi kecanduan games online siswa.

Kontrak perilaku merupakan suatu perjanjian antara anak dengan guru baik secara lisan maupun tulisan untuk berperilaku tertentu dan akan diberikan penghargaan (Wahyuni, 2016). Kontrak perilaku bertujuan untuk mengajarkan perilaku baru, mengurangi perilaku yang tidak diinginkan, atau meningkatkan perilaku yang diinginkan (Bradley T.Erford,2017). Konseling kelompok kontrak perilaku dilakukan sebanyak empat kali pertemuan. Pada setiap pertemuan membahas materi yang berbeda-beda.

Pertemuan pertama menjelaskan tujuan dilaksanakan layanan konseling kelompok kontrak perilaku serta pengungkapan masalah yang dihadapi siswa mengenai perilaku bermain game online. Pertama, membahas tentang permasalahan MR yang mengatakan sering bermain game online terutama pada pandemi saat ini siswa banyak menghabiskan waktu di rumah. Tidak dapat bermain bersama temanteman membuat MR jenuh dan memilih untuk bermain game online. Siswa belum menyadari bahwa perilaku bermain game online dapat berdampak pada akademik dan kesehatan.

Kedua, membahas permasalahan MAB dan YL mengatakan kondisi yang serupa, perubahan sistem belajar dari rumah membuat siswa merasa bosan karena tidak dapat bertemu dengan teman-teman di sekolah sehingga lebih memilih menghabiskan waktu dengan bermain game online. Sesuai dengan yang diungkapkan oleh Kusumawati. R (2017:90) games online sebagai media pelarian diri dari hubungan interpersonal dan interpersonal, konflik dengan orang tua, dan pengelolaan emosi yang buruk pada diri remaja sehingga mereka lebih tertarik dengan persahabatan virtual.

Ketiga, membahas permasalahan $\mathrm{J}$ dan MRT yang mengaku merasa lebih sering menghabiskan waktu bermain game online. Berbagai pilihan game online yang banyak dan variatif membuat $\mathbf{J}$ dan MRT tidak bosan saat bermain game online. Selain itu J dan MRT juga mengungkapkan tidak dapat mengatur waktu dengan baik karena keasikan bermain game online. Sebagaimana yang diungkapkan oleh Harlina A.P (2014:7) manajemen waktu merupakan perencanaan dan pengaturan waktu yang digunakan setiap hari dalam menjalankan semua aktivitas yang ada, berdasarkan pada skala prioritas dan jadwal yang telah ditentukan.

Keempat, membahas permasalahan siswa berinisial MRA, mengatakan lingkungan sekitar yaitu teman-teman yang hampir semua memainkan game online sehingga MRA pun ikut tidak mau ketinggalan untuk bermain game online.

Faktor konformitas (ikut-ikutan) dengan teman untuk mengisi waktu luang juga menjadi salah satu penyebab seseorang tertarik dengan kehidupan virtual (Rosi Kusumawati, Yolivia Irna Aviani, dan Yusi Molina, 2017). Siswa yang tidak mengalami penurunan perilaku bermain game online diduga karena pada saat melaksanakan kontrak perilaku sesuai 
kesepakatan hanya termotivasi untuk perilaku efektif untuk mengurangi perilaku mendapatkan hadiah dan menghindari hukuman. bermain game online di rumah dibandingkan

Peneliti menyakinkan bahwa dengan sebelum diberikan layanan konseling kelompok adanya dinamika kelompok yang baik dan tidak kontrak perilaku.

adanya tekanan dalam kegiatan maka dapat menunjang kelancaran kegiatan dan anggota kelompok semakin dapat menunjukkan sikap ke arah yang lebih baik. Dinamika kelompok juga berperan penting dalam pencapaian tujuan pelaksanaan konseling kelompok. Melalui dinamika kelompok setiap anggota kelompok diharapkan mempu tegak sebagai perorangan yang sedang mengembangkan kediriannya dalam hubungan dengan orang lain (Nashruddin,2019).

\section{SIMPULAN}

Tingkat perilaku bermain game online siswa di rumah kelas VIII SMP Negeri 15 Palu sebelum diberikan layanan konseling kelompok kontrak perilaku dikategorikan tinggi dengan sampel penelitian 6 siswa yang memiliki perilaku bermain game online tinggi. Setelah pelaksanaan konseling kelompok kontrak perilaku dengan empat tahapan yaitu tahap pembentukan, tahap peralihan, tahap kegiatan, dan tahap penutup. Terjadi perubahan prilaku yang siknifikan yakni 3 siswa berinisial MRA, YL dan MRT yang memiliki perilaku bermain game online tinggi, 3 siswa yaitu MAB, MR, dan $\mathbf{J}$ yang memiliki perilaku bermain game online rendah.

Perilaku bermain game online di rumah siswa kelas VIII SMP Negeri 15 Palu sesudah diberikan layanan konseling kelompok kontrak

\section{DAFTAR RUJUKAN}

Arikunto, S, (2006). Prosedur Penelitian Suatu Pendekatan Praktik. Jakarta: PT. Rineka Cipta

Anisa, P. H (2014) Mengembangkan kemampuan manajemen waktu melalui layanan penguasaan konten dengan teknik kontrak perilaku. Tersedia: journal.unnes.ac.id .

Lombogia, B.J., Kairupan, B., \& Dundu, AE. (2018). Hubungan Kecanduan Internet dengan Kualitas Tidur pada Siswa SMA Kristen 1 Tomohon. Jurnal Medik dan Rehabilitasi (JMR), 1 (20, 1-8.)

Bradley T.Erford. (2017). 40 Teknik Yang Harus Diketahui Setiap Konselor. Yogyakarta: Pustaka Belajar

Dewi, Priska, O., dan Pratiwi, TI. (2016). Penerapan Konseling Kelompok dengan Teknik Behaviour Contract untuk Mengurangi Perilaku Membolos Pada Siswa di SMK Kawung 2 Surabaya. Jurnal BKUNESA. Vol. 6 No.3

Masya, H. \& Candra, D.A. (2016). Faktorfaktor yang mempengaruhi perilaku gangguan kecanduan game online pada peserta didik kelas $\mathrm{X}$ madrasah aliyah $\mathrm{Al}$ Furqon Prabumulih tahun pelajaran 2015/2016. Jurnal Bimbingan dan Konseling, 03, (1) , 153-169.

Prasetiawan, H. (2016). Upaya Mereduksi Kecanduan Game Online Melalui Layanan Konseling Kelompok. Jurnal Fokus Konseling. Vol. 2 No.2 Agustus 2016. Hlm 116-125.

Budiman, H. (2017). Peran Teknologi Informasi Dan Komunikasi Dalam Pendidikan. Jurnal Pendidikan Islam. Vol. 8. No.1 
Dudi, J. (2017). Pengungkapan Diri Siswa Dalam Mengikuti Layanan Konseling Kelompok. (Studi Kasus di MAN Model Palangkaraya). Jurnal Konseling GUSJIGANG. Vol.3 No.1 .

Kamus Besar Bahasa Indonesia V. (2016). Kamus Besar Bahasa Indonesia Edisi Kelima. [online]. Tersedia:Https//bahasa.kemdiknas.go.id

Chalimi, M.K. (2017). Implementasi Teknik Behavior Contract Untuk Memotivasi Siswa Dalam Penyelesaian Pekerjaan Rumah Di Madrasah Tsanawiyah Negeri Pilangkenceng Madiun. Jurnal Pedidikan Islam.

Nashruddin, (2019). Penerapan Dinamika Kelompok Terhadap kemampuan Berkomunikasi Interpersonal Dalam Berdiskusi Pada Siswa SMP Negeri 2Tanete Rilau. Jurnal Bimbingan dan Konseling, Vol. 6. No.

Ismi, N., dan Akmal. (2020). Dampak Game Online terhadap Perilaku Siswa di Lingkungan SMA Negeri 1 Bayang. Jurnal of Civic Education, Volume 3 No.1 2020

Ningsih, Endang, Firman dan Erlamsyah. (2018). "Efektivitas Layanan Penguasaan Konten Melalui Bimbingan Kelompok Belajar dalam Mengurangi Perilaku Mencontek Siswa saat Ujian”. Jurnal Neo Konseling. Vol. 1. No. 1. Hal. 1-8.

Novrialdy, N., \& Ahmad. (2019). High school students understanding of the risks of online game addiction. Journal of Educational and Learning Studies, 2(2), 113-119.

Peraturan Menteri Pendidikan dan Kebudayaan Republik Indonesia Nomor III Tahun 2014 Pasal 1

Kusumawati, R., Aviani, Y.I. dan Molina, Y. (2017). Perbedaan Tingkat Kecanduan (Adiksi) Games Online Pada Remaja Ditinjau Dari Gaya Pengasuhan. Jurnal RAP UNP, Vol.8. No.1, Mei 2017, hal.88-99.
Lutfiwati, S. (2018). Memahami Kecanduan Game Online Melalui Pendekatan Neurobiologi. Journal Of Psychology. Volume 1. No.1

Suketi, S., Kurniawan, K. Mulawarman. (2018). Mengurangi Bullying Verbal Melalui Konseling Kelompok dengan teknik Kontrak Perilaku. Indonesian Journal Of Guidance And Counseling.Theory And Apliplication, 7(1)52.59

Sugiyono (2010). Metode penelitian Pendidikan Pendekatan Kuantitatif, Kualitatif dan Research and Development, Bandung: Alfabeta

Sukardi, Dewa Ketut. (2008) Pengantar Pelaksanaan Progam Bimbingan dan Konseling di Sekolah, Jakarta: RenikaCipta

Atikah, T.P. \& Sugiyo (2020). Keefektifan Konseling Kelompok Teknik Behavior Contract Untuk Mengurangi GejalaGejala Kecanduan Smarthphone. Jurnal Indonesian Journal of Guidance And Counseling. 1 (2) (2020) : 56-63.

Wahyuni, Septi. (2016). Peningkatan Kedisplinan Siswa Melalui Teknik Kontrak Perilaku (Behavior Contract) Di TK ABA Pakis. Jurnal Pendidikan Guru Anak Usia Dini Edisi 3 No. 270-278.

Jannah, Y.M. (2019). Konseling Islam Dengan Teknik Kontrak Perilaku Untuk Mengatasi Kecanduan Game Online Seorang Siswa Kelas 2 SMP Di Desa Tugusumberjo Kecamatan Peterongan Kabupaten Jombang. (Skripsi). 